\title{
The bases and methodology of deep ecology
}

\author{
Podstawy i metodologia tzw. ekologii głębokiej \\ Mieczysław Bombik \\ Institute of Ecology and Bioethics, Cardinal Stefan Wyszyński University in Warsaw, Poland \\ ORCID https://orcid.org/0000-0002-6459-5344• miet15@wp.pl
}

\begin{abstract}
The article includes the semantic analysis of basic terms and language phrases and synthetic depiction of following problems: the reformist organization of environmental protection, the sources of deep ecology, the basic theses of deep ecology, the political suggestions for solutions of environmental protection crisis, the organizational structures of deep ecology.
\end{abstract}

Keywords: deep ecology, methodology, social paradigm, ecological metaphysics, ecological policy

Streszczenie: Artykuł zawiera systematyczną analizę podstawowych terminów i zwrotów językowych oraz omówienie następujących zagadnień: reformistyczna organizacja ochrony środowiska, źródła ekologii głębokiej i jej podstawowe twierdzenia, wskazania polityczne dla rozwiązania kryzysu ochrony środowiska, struktury organizacyjne ekologii głębokiej.

Słowa kluczowe: ekologia głęboka, metodologia, paradygmat społeczny, metafizyka ekologiczna, polityka ekologiczna

\section{Introduction}

The presented characteristics of the ecological movement, which aims to be holistic philosophy of the field of biology which deals with the study of mutual relations between a man, other living organisms and their environment, called deep ecology, is based on a study of a leading representative of this field, Bill Devall: Die tiefenoecologische Bewegung, which appeared in Dieter Birnbacher's larger volume entitled: Oekophilosophie (Devall 1997). The study points to the diversity of sources, from which this ecological movement derives and benefits, with the fundamental principle which connects and unites all proponents of the movement, being granting the autonomic value to non-human beings, as well as to natural objects, classified as the so-called inanimate nature (Birnbacher 1997, 11). The term "methodology", used in the title of this article announces that norms, postulates and guidelines, formulated by the representatives of deep ecology, will be properly noted and accentuated, so that - in short - a man's attitude towards nature corresponded to the principles and a programme adopted and disseminated by the philosophy of the movement. Taking into account the rich literature which Devall refers to in his reflections, as well as translation of the statements of the quoted authors into Polish, is meant to bring closer to the Polish reader those foreign publications, which are very committed to dealing with the environmental issue.

"This article was originally published in Polish as Bombik, Mieczysław. 2005. "Podstawy i metoda tzw. ekologii głębokiej." Studia Ecologiae et Bioethicae 3: 381-406. The translation of the article into English was financed by the Ministry of Science and Higher Education of the Republic of Poland as part of the activities promoting science - Decision No. 676/P-DUN/2019 of 2 April 2019. Translation made by GROY Translations. 


\section{Name and initial characteristics}

There are, as Devall $(1997,17)$ writes, two large movements within the environmental protection movement of the second half of the 20th century. The first one, is the socalled reformist movement, that aims at preventing, among other things, high pollution of air and water, improper use of land in highly industrialised countries, trying to save, at least some of the remaining undeveloped areas, by including them in areas covered by nature protection laws. The second movement, contrary to the first one, is of a distinctly revolutionary character, manifested by its search for: new metaphysics, a new theory of cognition, new cosmology, and new environmental ethics for the system: a man - the Earth.

The name "deep ecology", first used by Arne Naess (Birnbacher 1997, 10), a Norwegian analytical philosopher, was intended to indicate, that it is about fundamentally revolutionizing the anthropocentrically oriented Western ethics and politics. Some authors propose other names for this movement, for example: "eco-philosophy" (Oekophilosophie), "fundamental ecology" (Fundamental-Oekologie), or "new philosophy of nature" (Neue Naturphilosophie). Devall advocates the term "deep ecology" (Tiefenoekologie), because it is relatively short, although, as he states, the terms "radical ecology" (Radikaloekologie) or even "revolutionary ecology" (Revolutionaere Oekologie) would be more accurate in relation to the content and a message of the movement. However, he believes that the last two names are too heavily loaded with emotional associations, so that, for example, the word "revolution" itself would make other, unwelcome references to environmental issues (Devall 1997, 17-18).

One of the important features of deep ecology, which must already be pointed out in the preliminary specification, is the postulate that the anthropocentric ethics of nature should be replaced with egalitarian ethics, which ensures equal moral status of all living beings, all living natural communities and species, and will change human consciousness to such an extent, that a man will not embrace his connection with the natural environment in a personality aspect. A modern man, by identifying himself with all-encompassing him and constantly affecting him nature, according to the advocates of the movement, will free himself from the constraints and various kinds of pressure he experiences while living in an industrial society and strive to build a holistically integrated Self, from which the motivations for ecologically correct lifestyle and $a$ new attitude of humility towards nature (voluntary simplicity) will then spontaneously emerge. So it is about newly oriented thinking, action and feeling.

This movement, unlike many other historical and contemporary environmental movements ${ }^{1}$, no longer wants to be a theory but proposes an ecologically conditioned way of living according to which a thinker, a poet, a social activist, a craftsman, a merchant, a worker, a housewife... will be working, in their specific area, for the ecological renewal. A respectful admiration for nature is not only to be a verbally expressed declaration, but also to be confirmed by action and expressed in the right way of living. Similarly to what it was like during the time of romantic philosophy of nature, philosophy itself should become part of the desired, holistic process, not just the rational implementation of the individual Self. The depth, that deep ecology refers to, is not only the spiritual depth of unity with nature, but above all, it is radicality of attempts to implement non-anthropological ecological ethics into the everyday way of thinking, feeling and acting of a man. Ultimately, this depth can only "manifest itself in its mystical inexpressibility".

${ }^{1}$ Historical can include, for example: 1) spinosism, 2) buddhism, 3) some versions of mysticism, 4) various varieties of nature theology, 5) panpsychism, 6) pantheism, 7) ethical naturalism realism, 8) ethical objectivity; to contemporaries: 1) reformist movement of environmental protection, 2) biocentric ecological ethics, 3) evolutionary ethics.

2 Those terms connected, among other things, with the English term "deep ecology" postulate, as it seems, to translate the term as "deep ecology" rath- 
From the point of view of the methodology of the language, which the representatives of the movement use, it should be noted, that some literary categories are also permissible in this language, while discursive justifications of the problem are often replaced with expressive - poetic ones. In the place of the old philosophical justifications, there are phrases such as: development of life or holistic life, which are meant to indicate unclear and vague ideals (concepts) of new harmony between a man and nature, such as: ecological justice, organic totality or ecological responsibility, without trying to more accurately establish the characteristic content of those concepts.

This kind of connection between the depth and mysticism, and the language used by the representatives of deep ecology, has however provoked - not surprisingly - a harsh response from the critics who, among other things, claim, that the movement has no theory at all, while R. Sylvan considers it to be simply a "conceptual swamp" (begrifflicher Sumpf) that threatens to sink in everything that makes ecological ethics attractive. ${ }^{3}$

Devall based his reflections and analyses, as he writes (Devall 1997, 18), on the studies of A. Naess (1973b, 95) and J. Rodman (1977) and on the work of philosophers dealing with, in the last 30 years, - of the 20 th century, the development of deep ecology. Only a few of those works have appeared in easily available journals or in multi-copy book editions. Devall examines this material in terms of answering four questions that he believes are relevant to the comprehensive characteristics of deep ecology: 1) sources of deep ecology; 2) differences between the premises of deep ecology and the premises of a socially acceptable paradigm; 3) differences between deep ecology and the environmental reform movement; and 4) the future of deep ecology.

er than "a depth of ecology", without suggesting, in case of the second translation, any intuitive analogy between ecological "depth" and psychology of depth.

${ }^{3}$ For more data on general specification of deep ecology, see (Birnbacher 1997, 7-15).

\section{Widely accepted paradigm}

The term paradigm made a remarkable career in the field of natural science methodology in the second half of the 20th century. The main architect of this concept was, as we know, T. S. Kuhn. The critics, however, have pointed out that the concept is remarkably polysemous. For example, Ms Masterman has counted 21 different meanings that are related to this technical term (Masterman 1970). Therefore, using this term, we need to clarify it. This is done by Devall, who is no doubt closer to the definition of the paradigm as a model of natural order proposed by S. Toulmin (1961) Devall states that, he wants to understand paradigm as a short description of certain way of looking at (a certain perspective) the world; as a unity of: values, beliefs, habits and norms of a certain group of people - for example, people of the same state, the same religion, or the same social layer. The prevailing social paradigm is the thought (spiritual) image of a social reality that defines the expectations of a given group.

Using the paradigm as a tool to describe the social reality, that is close to him, Devall believes, that the paradigm present in North America certainly contains following beliefs: the belief that economic growth, understood as the gross calculated value of the social product, is a measure of progress; the belief, that the prime objective of the government - following a protection of the state - should be to create the best conditions for the growth of the production of goods and to optimally meet the material needs of citizens; the belief that technology is capable of solving human problems. According to this paradigm, nature is only a resource store that needs to be opened to meet the ever-increasing needs of a numerically expanding population. Science and technology cooperate to achieve this goal. Technology develops techniques for directing, or controlling, natural processes, such as weather conditions. Changes become a targets for themselves. The new one, is considered as more valuable than the old one, presently living 
generation, better than past generations. The aim of life is to satisfy individual needs and to increase living standard, manifested by possession of, for example: a house, a car, products enabling pleasant leisure activities, etc. (Pirages and Ehrlich 1974). Regardless of the sources of the origin of this paradigm and the conditions it was formed under, it is, states Devall, still existing, officially praised (e.g. by advertisement) and an important factor in shaping the vision of the world of most residents of North America. ${ }^{4}$

The issue of the genesis of the prevailing paradigm is a moot point. Dewall identifies three groups of authors trying to solve the issue in different ways (Devall 1997, 20). Some believe that the roots of the prevailing paradigm lie in Judeo-Christianity (White 1967). Others place its cradle in the ideology and structures of capitalism, considering capitalism responsible for excessive air and water pollution, for increasing centralisation of political and economic power, for ignoring future generations, and for irresponsible use of natural resources of nature (Weisberg 1971). Others point to its source in Locke's well-known view, who believed, that owned property, in order to serve well its owner and a society, should be continually "improved" (Ferkiss 1974).

After reminding the role and functions that, according to Kuhn, the paradigm plays in contemporary science and how it influences the attitude of scientific researchers, who practice "normal science" (Kuhn's term) within this field, Devall stresses $(1997,20-21)$ the causes and situations, an emergence of which may lead to a change in the existing paradigm in general. This can occur when a certain group of people (a research team), comparing empirical predictions of a universally acceptable theory, claims that the observed facts are inconsistent with expectations. Similarly, a change in the social paradigm can occur, Devall states, when, for example, some charismatic social leader, some social movement, or some small commu-

\footnotetext{
${ }^{4}$ About the history of leading social paradigm see (Ferkiss 1974; Lasch 1979).
}

nities discover new solutions that can announce a change in the current commonly prevailing paradigm.

\section{Environmental protection reform movement}

Deep ecology is contrasted with other, past and present ecological movements, which Dewall gives a common name: Environmental protection reform movement. A common characteristic of those movements is that they seek social change aimed at achieving a "higher (better) standard of living", without questioning the premises, from which the formulation of the existing social paradigm is derived. Each of those movements identifies a specific problem that is dealt with by various, cooperating volunteer organisations, actively working towards social change.

There are at least eight such environmental movements in the 20th century, mostly in America, that are, according to Devall, worth mentioning

1. The movement of creation of urban parks, creation of nature reserves and national parks (Nash 1973; Sax 1976);

2 . The movement of reducing the risk of health loss and general safety, as a protection against the phenomenon of widespread use of technology at the time of industrial revolution (Commoner 1971). For example. The Union of Concerned Scientists informed the public about the risk to public health and safety caused by generating nuclear electricity by nuclear power plants.

3. The movement for the development of awareness of proper use of land in agriculture and the associated movements of the late 19th century of beautification of cities, of division of land into defined zones according to planned use of the land, and the modern-day, powerful and strong debatable - polemical movement of division of sea coasts (National Resources Defense Council 1977; McHarg 1971);

5 The literature presented following Devall can facilitate an access to detailed information on the characteristics of mentioned ecological movements. 
4. The movement for the secondary use of natural resources of land represented by Gifford Pinchot Zozofl and U.S. Forest Service (Rodman 1977b, 2; Hays 1959; Pinchot 1947).

5. The movement of the 1960s and 1970s called: back to the Earth (Zurueckzum-Land), with its ideology of organic farming;

6. The emergence of groups of a high rate of population growth, e.g. groups: zero human population growth (Ehrlich 1968; Report 1972);

7. The movement: freedom of people and animals, committed to the need to change the attitude of people towards animals (Regan and Singer 1976; Singer 1975);

8. The movement: boundaries of growth (Grenzen des Wachstums), which postulates the need to control population growth in order to become a "a society of stable numbers" (Meadows and Meadows 1974; Mesarovic and Pestel 1974; Meadows and Denis 1977; Cole 1973; Daly 1973).

\section{Sources of deep ecology}

The whole issue of deep ecology grows out of, as it is strongly emphasised by Dewall $(1997,23)$, a certain vision of a man who can exist neither above, nor beyond nature, but is part of nature. This vision should be the source of the whole, one might say, methodology of thinking and lifestyle of a modern man: a man should care for nature, protect it, relate to it with due respect and dignity, enjoy being a co-inhabitant of the "House called the Earth" (Haushalts Erde), allow to live "all that is alive" (Lebendiges leben) and agree that the whole nature that exists outside him can develop according to evolutionarily established regularities.

The program of the reformist movement of environmental protection, in comparison with the program of deep ecology, turns out to be pragmatic and short-sighted. It is aimed at achieving only certain goals, for example, a ban on building nuclear power plants or maintaining clean water in rivers. Deep ecology, from the very beginning of its existence, has sought to identify and discuss, alternative approaches to the existing patterns of the modern West way of thinking. Hence, it assesses some solutions of the reformist movement as inaccurate or even useless, and aims, above all, to change the value system and to change social organizations.

A historian Lynn White, in his influential article from 1967: The Historical Roots of Our Ecologic Crisis, argued, that at the root of the prevailing social paradigm lies the image of a man opposed to nature; the image of a man and nature remaining at war with each other. Other authors, of various intellectual orientations, have also criticized the existing paradigm and the one-sided scientific perspective of the Western world (White 1967), based on it.

One of the main sources of the emergence and development of deep ecology was the influence of the spiritual traditions of the East, which Alan Watts and Daisetz Suzuki (Watts 1975; Watts 1970; Watts 1955; Watts 1977; Suzuki 1961) began in the 1950s. Eastern traditions brought an entirely different picture of the relationship between a man and nature. At the same time the so-called Beat-Poeten - such as Alan Ginsberg- look for a new way of solving psychological and spiritual problems using the Eastern philosophy. Those are problems related, for example, to all kinds of rape, mental illness, human alienation from others, from the environment, from nature. From a later perspective, however, it must be concluded, that those Beat-Poeten were a group that understood the Eastern philosophy, ecology, and philosophical traditions of the West in a relatively naive way. The exception was Gary Snyder, who is considered one of the most influential eco - philosopher of the 1970s.

In the late 1960s and later in the 1970s, an increasing number of philosophers, scientists and theorists of society undertook comparative analyses of the Eastern and the Western philosophical traditions in relation to science, technology, the relationship between a man and nature. For 
example: Carpa's Fritjoff points out the apparent parallels between certain Eastern philosophical directions and the physical theories of the 20th century (Capra 1975); Joseph Needham made the Western readers aware of the incredibly high scientific, technical and civilizational levels that had been reached centuries ago by the East, and presented alternative science and alternative systems of value of the East. In addition, he proposed to use the achievement of the Eastern philosophers in the West, as the spiritual and ethical core of contemporary science (Needham 1954; Needham 1976, 1); the work of Huston Smith contributed to a revitalisation of research concerning the relationship between the degradation of the environment and the value system of the Western social paradigm. Smith and other authors sought a new spiritual and religious pattern in the various philosophical systems of the East (Smith 1976; Smith 1972, 62-81).

Some philosophers of the social sciences have merely settled for publication of accurate critics of the Western society, not offering any new metaphysics for their views, and have not made any reference in their analyses to the Eastern philosophy. This is the position of Jaques Ellul, for example, who has taken up the issue of technology and a technical society (Ellul 1964), Paul Goodman, has initiated a discussion with a question: is an existence of a humane technique possible (Goodman 1973, 225), Herbert Marcuse, with his analysis of a one-dimensional man as a prototype of the modern burgher (Marcuse 1964). Also the work of Theodore Roszak highly influenced those philosophers, who, seeing the shortcomings, flaws, imperfections and errors of social behaviour nowadays, thoroughly criticised the premises leading to the formula of the prevailing social paradigm (Roszak 1969; 1972; 1975; 1978).

The second thought direction that has contributed to deep ecology emerged in the 1960 s and 1970s, was an attempt to look in a different way (a new assessment) at the native inhabitants of the Americas and other prehistoric people. It was not, however, a reference to the romantic image of Indians as so-called noble savages, but an attempt to evaluate objectively and critically, through the comparative analysis, the traditional beliefs, philosophy, and social organizational forms of American Indians. This analysis was to answer, for example, the following questions: How different tribes coped in different time periods with the changes in their natural environment (e.g. long-term drought), or with technical progress? What were the character features of American prehistoric people? Are modern people, who belong to the Western cultural circles, able to get to know those special character features and understand them in a phenomenological way? According to the experimental research, related to this issue, carried out by Carlos Castaneda, it is very difficult for modern people to get an accurate understanding of this matter, as it assumes a fundamental change in the vision of the relation a man - nature. Moreover, Robert Ornstein believes, that the research of Castaneda lead to the conclusion, that the Western educated intellectual is virtually unprepared to understand those, often very esoteric traditions (Ornstein 1976, 105). For numerous experimental and research works of C. Castaneda, see in.: (Castaneda 1974a; Castaneda 1971; Castaneda and Carlos 1974b).

The following text from the work Touch the Earth, published in London in 1971 (in German):: Wie der Hauch eines Bueffels, Hamburg 1979, by T. McLuhan, and this is a statement by Luther Standing Bear, a native Indian from the Oglala Sioux tribe, which, according to Devall, contrasts particularly well with the view of nature of the original inhabitants of the Americas and the one of a civilized man, based on the modern social paradigm: "When we hear the word wild, we do not think of a wide open prairie, of beautiful mountains, rolling hills or streams that had sought their way and absorbed each other. The nature was wild only according to the view of a white man and only according to his view, this country was inhabited by wild animals and wild men. For us, nature 
was homely. The land was fertile and we were surrounded with the blessings of the Great Mystery. It was only when the hairy man from the East appeared and, in a fit of brutal rage, began to hurt us and our loved families, we learned what the word wild meant. When the first animals rushed to escape, it became clear to us: the Wild West had begun" (Devall 1997, 26).

The third source of deep ecology are the religious and philosophical minorities of the Western tradition. G. Sessions claims, that in the history of the Western civilization, it is possible, in some respects, as if with a thin thread, to combine: the Presocratic philosophers, Theophrastus, Francis of Assisi, Giordano Bruno and other neo-Platonic mystics, reaching as far as Spinoza, and then: oreau, John Muir, Santayana, Robinson Jeffers, Aldo Leopold, Loren Eiseley, Gary Snyder, Paul Shepard, Arne Naess to Edward Abey, nicknamed "The Desert Rat". Those minority traditions could, in Sessions' view, despite the presence of many elements differentiating them, provide a solid basis for the creation of a timeless, mutually inter-fluent whole with a real balance merging three, often artificially separated from each other, component parts: God - nature - a man (Sessions 1977, 481).

G. Sessions, A. Naess and S. Hampshire point out Spinoza as a philosopher who has accomplished, unparalleled in history, unification of consistent metaphysics concerning a man and nature with modern European science (Hampshire 1977; Hampshire 1956; Naess 1977, 45). Spinoza's ethics implies egalitarianism towards all living beings. The value of science, according to Spinoza, comes from the fact, that it enables contemplative vision of the pantheistic and sacred universe, and spiritual development and organization. Spinoza dissociates himself from other 17 th century philosophers - such as Bacon, Descartes, Leibniz - who, at the time, were constructing the foundations of technological, industrial, and social paradigm intended to be the fulfilment of the Christian commandment according to which a man should rule over the whole nature.
As the 20th century "evangelist" of Spinoza was considered a poet and a philosopher Robinson Jeffers, who spent a majority of his life on the coast of California near Big Sur and gave Spinoza's philosophy a distinct ecological interpretation (Sessions 1977, 481; Coffin 1971; Hotchkiss 1975). European philosophies, who are most often referred to by the advocates of deep ecology, are A. N. Whitehead and M. Heidegger. A growing number of philosophers and thinkers, especially in America, interested in ecological consciousness and modern philosophy, consider M. Heidegger's critique of the Western philosophy and the Western societies (Whitehead 1925; Griffin 1972, 95; Heidegger 1954; Steiner 1978; Vycinias 1961; LaChapelle 1978; Zimmerman 1977, 74; Sheehan 1981).

The fourth source of ideas and problems of deep ecology is ecology as a scientific discipline. For some, this is the science of "managing a household", taking into account all specific conditions needed for such a project. For others, ecology is a specific perspective, a specific point of view. This second understanding is especially important, because ecology as science can be quickly appropriated by technological "passionates" who want to "improve", "humanize", and "govern" everything that is alive. Two ecologists, W. Murdoch and J. Connell (Murdoch and Connell 1973), warned against this kind of "ecology" in the early 1970s. They write: "Even when, we do not claim that ecologists are kind of engineers of environmental protection, comparable to physicists, giving engineers scientific guidelines how to act, one can ask: does this understanding [...] provide technical environmental managers sound operating principles? Surely, not. [...] We argue, that ecology as such is unlikely to give what many expect of it; it is unable to develop asystem of rules that would be able to protect the environment" (Devall 1997, 28-29).

A similar view is shared by $\mathrm{D}$. Worster in the epilogue of his historical presentation of ecological thinking in the West (Worster 1977). However, in deep ecology, ecologists play an important role, they can, 
among other things, conduct subversive activities. According to P. Shepard, who deals with human ecology, "the ideological status of ecology is a kind of opposition movement" because its initiators, such as A. Leopold, challenged the most important assumptions of the prevailing social paradigm (Shepard 1969, 1; Evernden 1978, 1620). Worster, in the above-mentioned history of ecology, states clearly: "Although every science deals primarily with what is, the cultivators of it come across, what it should be. The persistent environmental crisis shows that moral visions and utopias of a man become nothing more than empty formulas, as soon as they stray too far away from the natural processes of nature. This is an important lesson, which, the study of the effects of human activity on the environment, has taught us. The ecological ethics of the interrelationship between a man and nature could be the result of the dialectical relationship between scholars and ethicists" (Devall 1997, 29).

The last source of the inspiration for the broadly understood deep ecology are, according to Devall, artists who have tried to connect the thought included in their works to a specific place (Huth 1961, 60; Shepard 1977, 22). Some of them, defying certain trends of the mid - 20th century - e.g. pop artists, artists associated with minimal or conceptual art - demonstrate a notable clarity and objectivity in nature perception. Such spiritual-mystical objectivity is reflected in, for example, photographs of A. Adams (Adams 1961, 49). For those people of art, a man, through his artistic creation, confirms a spiritual kinship with eternity and God. Those include also M. Graver, who incorporated the concepts of the Eastern philosophy (together with Zen-Buddhism) into his work, and L. Cray, with his images of heaven, showing the richness of light of nature revealing itself to us (Graves 1974).

\section{Basic theses of deep ecology}

Many authors, who have challenged the foundations of the prevailing contemporary social paradigm, attempt to develop new: metaphysics, theory of cognition, and ethics, which are meant to be suitable for - as one might say - appropriate ecological consciousness. Some of them are involved in the reformatory movement for environmental renewal, although they are aware, that a reform in the form of some modifications in this area is not sufficient, that a new paradigm and a new vision of a proper economy and another good society is needed, as an alternative to the existing one (Sibley 1977, 251).

Aldo Leopold postulated, for example, that new visions should not begin with arrangements concerning the nature of a man or his needs, but, we should try to think like a mountain, that is, to understand how inanimate nature would think in terms of environment protection. This way of addressing the problem is an important component of the phenomenology of ecological consciousness. The native principle of deep ecology is the thesis on the unity of nature, not dualism: a man - nature, adopted by Western philosophy. A philosopher Henryk Skolimowski writes: "We are currently in a phase of an agitated process, in which, we must challenge the boundaries of the analytic and empirical understanding of the world and develop new conceptual and philosophical approaches, enabling us to solve numerous new social, ethical, ecological, theoretical and ontological problems. Everyone feels the need to build a new and basic philosophic scaffolding. It would be lamentable, if professional philosophers were the last group of people to notice it" (Devall 1997, 31).

Numerous authors and representatives of deep ecology, including: W. Ophuls, E. F. Schumacher, G. Sessions, Roszak, P. Shepard, and G. Snyder or A. Naess, expressed a demand for the formulation of a new social paradigm or new environmental ethics. Referring to A. Leopold's saying: think like a mountain, R. Nash writes (Nash 1977, 2): "Do rocks have rights? When the time comes, that this question is no longer going to be funny to many of us, it will be a sign, that we are at the threshold for a change of the value system, that will enable us to work out the resources needed to tackle 
the worsening ecological crises. One would hope it's not too late" (Devall 1997, 31-32).

Any attempt to artificially create an ecological ethics, or a new ontological attitude of a man in nature, on various theoretical grounds is, according to Devall, likely doomed to failure. However, he believes, that if we stand on the ground of fundamental issue of the intellectual mainstream called deep ecology, it can, at least, provide material for further clarifying and organizing discussions. Among the fifteen thematic groups, which capture the basic tenets of deep ecology, there are clear principles: metaphysical - religious, psychological - espitomological, ethical, socio -economic - political. Devall also points out, that the issue of deep ecology covers most of the theses of the reformist environmental protection movement, including them in the fundamental critique of the prevailing social paradigm.

If we present the basic theses of deep ecology in a postulative form and additionally consider the question of justification of those postulates, we will determine, more closely, what is called the methodology of deep ecology in the title of this study.

1. A prerequisite for the construction of the new eco-philosophy should be new, cosmic - ecological metaphysics that would emphasise the "I - You" identity between a man and the rest of nature.

For deep ecology, the totality and integrity of a man and the planet Earth, together with the basic statement of biological equality of birth - as A. Naess calls it, is something originally essential. A man is an integral part of nature, standing neither above nor beside it. A man is a humble inhabitant of the biosphere, not the conqueror or the leader of it. According to St. Francis of Assisi, a democracy of all God's creatures should rule the world, or, as Spinoza argues, a man is a transitional and independent way of existence (modus) of the whole: God-nature. A man flows together with the system of nature, rather than is able to direct the whole nature that exists outside of him, which he only slightly touches. He does not bring nature to perfection and it is not his job to improve it (Needleman 1975, 76-77 and 100-102).

2. An objective attitude towards nature is desirable.

This requirement can be found, for example, in Spinoza's and in F. Jeffer's works, the 20th-century student of Spinoza Jeffers defines his philosophical position as inhumanism, to indicate that, this philosophy sharply, even shockingly, contrasts with the subjective anthropocentrism prevalent in the twentieth-century Western philosophy, art and culture.

3. A new psychology is needed, that would integrate metaphysics with the spiritual area of post-industrial society.

The fundamental change of a paradigm is always a result of a psychological change in a way of perception. The new paradigm demands moving away from the dualism: subject - object and a man - nature dualism in favour of a consciousness involving all the interrelations of the areas and domains of the planet Earth. Psychotherapy adjusting a society to my person (to my Self) is to be replaced with a new ideal of psychotherapy, understood as a spiritual development. New metaphysics and new psychology lead, with logical consequence, to a state called egalitarianism, in relation to all living things, leading to liberation, in the sense of the psychological and emotional autonomy of individual and spiritual development, Homo sapiens, to the right to develop, other than a man, living species, according to their purpose determined by evolution (Sessions 1977, footnote 41).

4. Environmental protection should have an objective basis, but objective science, in terms of the new paradigm, differs from the currently widespread, narrow, analytical approach of the "scientific method".

Science, built on the wisdom of ancestors, should be objective and should participate in contemporary science, without taking on its duality: subject - object. The main value of science is seen in its ancient context, i.e. in a contemplative view of the cosmos and a better understanding of our Self and the whole Creation. 
5. Knowledge should arise from a stability of natural processes that occur without human intervention.

The massive destruction of ecosystems caused by a man is unethical and harmful to a man. Settlements of people should be planned taking into account all environmental conditions and not separately from them.

6. The well-being and quality of human life should not be measured only by the quality of produced product.

Technology should take back its former place - as a practical tool making everyday life easier, and not becoming a target itself.

7. The optimal use of the Earth should be determined, as human biosphere, including optimal use of individual islands, valleys and continents.

Drastic regulation of the birth rate of homo sapiens is desirable, using humane birth control programs (Schumacher 1973; Ehrlich, Ehrlich and Holdren 1977).

8. Dealing with the symptoms of the conflict between a man and nature, for example air or water pollution, can obscure major environmental problems and thus make them more difficult to solve.

The economy must be subordinated to ecological and ethical criteria. It should play a minor role in the new paradigm, not without reason, as a small branch of ecology (Ophuls 1977).

9. New philosophical anthropology should be used to acquire and use the knowledge of hunting and foraging, in order to build, based on this knowledge, the rules of life necessary for healthy and environmentally properly functioning society.

Reaching a phase called an industrial society should not be the goal of development of all societies. Hence, consideration of the re-settlement of the country by social groups, whose primary and standard activities will be hunting, foraging, creating and cultivating gardens in a post-industrial society (Shepard 1973; Berg 1978) should be taken seriously.

10. Diversity is a highly desirable value not only in culture, but also in relation to health and stability of ecosystems (Dasmann 1978; Myers 1979).
The ideal of deep ecology, therefore, is not some global trans-globalism, which seeks to unify, at all costs, all forms and manifestations of social life, according to indicated, common patterns.

11. There should be a rapid switch to "soft electricity supply" and "adequate technology" and lifestyle that allow for a significant reduction of energy demand "per head" in highly industrialised countries. At the same time, the supply of energy to remote regions, socalled "the third world", should reach an appropriate level.

Representatives of deep ecology advocate for creation of a stable state, or a protective and caring society, as soon as possible, based both on the principles of ethically proper integration of a man with nature, as well as acceptance of ecological reality. A further goal should be to integrate a highly developed, often sophisticated, safe, and not ecologically objectionable, well-adapted technology into a highly reduced and varied, organically and productively efficient agriculture, in which again, as it was in the past, such activities as hunting and foraging will not play a minor role (Dasmann 1973).

12. The aim of education should be to stimulate the spiritual and personal development of members of a society, to prepare them, not only to perform the type of work which would suit the oligarchically organised and a consumer-oriented industrial society.

The postulate shows concern for the comprehensive spiritual and mental development of an individual human being, and warns, at the same time, against the production of human - robots, one-sidedly specialized and devoid of general human values.

13. It is proposed to increase the amount offree time in order to be able to engage in art, sport, music, dance - so that fun will, once again, become a source of happy life and cultural achievements (Huizinga 1956; Collier 1969).

There is a clear recognition of the value of free time, properly used and managed, which can serve as a complementary func- 
tion of bringing up and educating a man, and at the same time, it can be an area of testing and fulfilling his/her personality.

14. Local autonomous and decentralized management systems should be independent of the central political power and of the oligarchically organized bureaucracy.

Even if bureaucratic organizational forms function better, other organizational forms are much more effective, in the light of the basic principles of deep ecology, especially for smaller communities (Pirages 1977).

15. Until a stable economy and fundamental social structures is developed, significant areas of the Earth's biosphere should be isolated, and excluded from further access to industry and dense population; those areas should be protected by specially appointed security units Some refer to it as the world wildlife police ("Welt-Wildnis-Polizei”) (Iltis 1972, 167).

\section{Political proposals to solve the environmental crisis.}

The main theorists of the environmental movement, as well as deep ecology, believe, claims Devall, that the environmental crisis is not a transient phenomenon, and even that it will worsen. Environmental activists within the reformatory movement argue, of course still, that all problems can be solved within the current social paradigm. They postulate, for example, to redraw the relevant laws and establish the extent of the responsibility of private owners, to establish more laws to discipline those who pollute the environment, to expand the scope of motivations that encourage getting out of this misery (Hardin and Baden, 1977; Passmore 1974), which is the visible degradation of the environment. Some are trying to extend the positive laws (established) to the natural environment, to the extent that, the common law will guarantee every human being the right (with the possibility of a judicial challenge) to a habitable environment (Sax 1971).

Other representatives of the reformist direction argue, that small, gradual chang- es in legislation and social institutions are all that can be achieved in the present situation, in order to advance political traditions favourable to accept the point of view, that the natural environment should have a certain qualitatively defined level (Bond 1977, 31). The demands made to seek alternative sources of production, e.g. electricity produced by traditional means, in relation to obtaining it from nuclear power plants and political and economic programmes built on them, do not necessarily have to refer to the need for the construction of new metaphysics or theories of cognition, or change of religion In addition, neither reformists nor the representatives of deep ecology, call for any kind of revolutionary change of existing social-political institutions or to bring down the governments (Odum 1973, 516; Nash 1977; Leiss 1976).

Environmental advocates, such as Bond, argue, that power-hungry visionaries achieve very little: "a discussion that stops at the theoretical level is unrealistic, risky, and uninteresting, as a way to create effective environmental ethics" (Devall 1997, 37). Nevertheless, the reformists consider themselves as realists and pragmatists, and postulate: "the extension, diversification, and perfection of existing socio-political traditions or positions, which - even if they are not yet leading - are not, however, outside of the scope of our overall experience" (Devall 1997, 37), and which best serve protecting of the environment (Cahn 1978).

More radical members of the reformist movement of the early 1980s, point out, the need for deeper social changes to effectively protect the environment. The 1979 Greenpeace Chronicle's main article (Greenpeace 1979) reads: "Humanistic systems of value must be replaced with over humanistic systems, which will make life of all plants and animals subject to legal, moral and ethical attention, and in the longer term -whether one likes it or not - coercive measures will have to be applied to those, who act to the detriment of the environment" (Devall 1997, 38). 
The tactics of the environmental protest movements can be described as peaceful, but since the 1990s, direct protest actions have been relatively common, for example, against whale hunting (Greenpeace), or against the existence or construction of nuclear power plants (various anti-nuclear groups) (Barkan 1979, 19).

Deep ecology theorists believe, as argued by Devall, that everything the environmental movement was able to propose was taken over by deep ecology. However, it is not enough just to amend the laws concerning air and water pollution, to issue regulations to ensure safety of the construction and operation of nuclear power plants, or to designate relatively small areas for $n a$ ture protection. This type of remedial procedure regarding the existing phenomena, turns out to be not very effective or simply ineffective. At best, it is only a matter of time-limited action, by use of which the process of pollution and contamination of the environment is attempted to be controlled, that had originated "by consent" from the existing paradigm.

Although, deep ecology calls for fundamental changes of attitudes and relating to the environment, it does not have a clearly formulated political - economic agenda, and many of its theorists even believe, that such a program would be ineffective and pointless at the present time. Thus, the representatives of this movement, are limited to criticising the prevailing social paradigm and to developing alternative, very general visions of a man as a part of nature, without specifying how to implement those visions. This is also the nature of Gary Snyders' book: Four Changes, written in the 1970s, and to this day, Devall believes, is the most intelligent political publication of deep ecology (Snyder 1970, 323).

In the late 1970s, T. Roszak and R. Dasmann attempt to accurately describe, what specific changes of social life are to be about. Both of them prefer existence of small communities. Roszak proposes to revive old households, while the search for one's own personality should be combined with the development of ecological aware- ness. Dasmann developed plans of resettlement of the areas devastated by the plundering economy of past generations. His ideal is a society that is a decentralised, anticipatory and caring community. P. Berg and R. Dasmann, for example, answer the question of how this kind of creative social disintegration can be constructed, in relation to post-industrial society. Inspired by the way of life of the native inhabitants of America, who had inhabited north-eastern California many thousands of years before the invasion of a white man, and were able to come to some comfort of life and produce a relatively rich and varied food, those authors create ideas of future primitive people and living in one place. They developed a theory of recolonization, according to which humans "lead an active life and develop social forms of behaviour, in order to enrich life in every place, renew systems that serve life and in a given region, to follow socially and ecologically appropriate patterns" (Devall 1997, 39).

Other representatives of deep ecology believe, that one should join the reformist movement, which takes on the ecological opposition, seeking to confront, to show specific actions, or to directly dramatise the ecological crisis. J. Rodman (1978, 54) understands environmental protest as: "a defence of the integrity of the natural, multidimensional Self in the multidimensional world. The aim of the protest does not depend on success or failure in some linear connection of events, but it lies in the multidimensional depth of an action relating to a particular area, although the guiding principles of this action are also important in many other areas. This way, the ecological protest contains something of a ritual, through which one's Self is expressed in conformity with the order of existent things" (Devall 1997, 40).

Taking into account the above formulated postulates, proposals and positions, it can be concluded, that the new paradigm of deep ecology is of a revolutionary type in its metaphysics, theory of cognition, and cosmology, but its representatives do not seek to force (with the help of the army, or 
weapon...) to change governments, nor do they seek holistic political agendas, which they would want to use to create a new order of the world.

The contemporary deep ecology movement is rather - as R. Nisbet accurately put it - a movement of return and renewal (Rueckzugs - und Erneuerungsbewegung), that has continued to appear in the Western society since the fall of the Roman Empire (Nisbet 1974, 319), and which can be characterized as follows: "It would certainly be wrong to describe this kind of society as a politically revolutionary society. [...] There is no doubt, however, that this community is characterised by a kind of radicalness, but the revolution is not an essential feature of it. The most important goal of revolutionary action is to overturn, overthrow the existing social order and to seize power directly, with the help of forceful solutions, that are aligned with revolutionary strength and revolutionary concept, while the goals and ideas [of ecological community] have a peaceful character - apart from a few exceptions. They have nothing to do with violent seizure of power or rejection; they are carried out without coercion, by example and vision rather than by revolutionary rape and the centralization of power. The voluntary establishment of autonomous and mutually free relations between people, who are presumed to be corresponding to nature and morality of a man, and not imposing them by the government, army or police is the basic goal of the social ideal in Western social thinking, which I call ecological" (Devall 1997, 41).

Deval emphasized, that there is no deep ecological political party, there are no politically revolutionary cadres. Those kinds of structures are for the representatives of deep ecology, a wrong way, are unacceptable. Direct confrontations with the reformist defenders of the environment or with representatives of existing social or political order, are also undesirable. Keeping people ready for ideological defence is not of much use. Deep ecology does not want to be one more ideology in the world filled in with ideologies. It wants to look for ways leading to revealing and shaping ecological awareness. From this awareness, an ecological protest, will naturally flow. J. Rodman took over H. Marcuse's concept of reception capacity (Faehigkeit zur Rezeptivitaet) to speak, with its help, of the search for ecological awareness and ways of liberating nature (Rodman 1977a, 83). However, he points out: "The mere reception capacity does not yet lead to action. The possibility to act is conditioned by the knowledge that on the other side of the perceived diversity, we can see an individual soul (psyche) of the community and of the whole cosmos as a metaphor for the other (something else), and that the old saying "to live according to nature" can be well illustrated today with the maxim of oreaus: Make your life a grain of sand in the machinery modes which would lead it to stop" (Devall 1997, 42).

The representatives of deep ecology see their contribution to the development of ecological awareness in the fact that they want to be an example of proper behaviour and to teach this way. This enlightening action is a process, by which, one's own ecological awareness, as well as that of others, will be preserved and will be further developed. Some people, such as G. Snyder, want to perform functions that are not particularly valued in society. A. Watts in his book: Psychotherapy East and West comments on this attitude: When a teacher wants to change the ways of perception of his student, his view of the world, the basis of his personality (Ego), the best method is not a confrontation, attack or admonishing. Direct confrontation usually results in attitudes of hostility, fear, closure, rejection. As an example of a model behaviour in this case, he shows Watts Orpheus, a priest, who was the voice (tube) of the gods and who was able to tame people and animals by seductive charm of playing his harp. His method is not that of preachers or politicians, but that of artists, in its most fundamental sense (Watts 1977, 182).

In the system of civilization values, in the daily struggle for survival, the artist does 
not play any role. Rather, you see someone who merely beautifies life, who amuses us, while we do our work. As a wandering musician, clown or poet, he is welcome everywhere, because nobody takes him seriously.

This is exactly the role that, in deep ecology, played a poet and a philosopher G. Snyder. He leads an exemplary life, in accordance with the concept of re-settlement, on one of the hills near Grass Valley in California. He travels all the time, recites his poems and talks to people he meets. He wrote about the return of a man - coyote, a crook, a man - animal of American Indians, who constantly reappears in the history, passed on by means of oral tradition of many Indian tribes. These allegories and stories often have different endings, but they always have a certain message - not explicit, not intrusive, but deep (Snyder 1997. Critical remarks regarding the work of Snyder: Steuding 1976).

In one of his essays, Snyder writes: "The coyote man was interesting to me and to some of my colleagues, because he gave us some information about a particular place, where he had appeared and became almost a patron of that place. The other side of him had to come out of something stuck within us. A kind of fascination emanates from this impostor. His picture is well-known. In some cultures he is hidden or changed, in other, he is partially, but substantially modified. For me personally, I think, it was psychologically interesting, to see that there is no strong and clear dualism between good and evil in this figure, that his way of acting is kind and compassionate, he helps people and radiates a certain dignity. But sometimes he acts like the most stupid fool. The most common picture of him is, that the coyote man constantly wanders and tries to do the best he can, as much as he can. [...] So if the figure of the coyote man entered modern American lyricism, it is not only because of his relationship with the place. It is also created by a world-famous resource of myths, stories and motives. This is what lyricism has been doing for a long time: it reached back to historically native images, refreshed them, carefully modified them and combined them with a specific time and place" (Devall 1997, 43-44).

\section{Organisational structures of deep ecology}

While the environmental reformist movement is satisfied, says Evall, with the cooperation with administrative units and institutions forming - legal regulations and active participation in existing environmental protection organizations, such as: Sierra Club or National Audubon Society, the representatives of deep ecology do not trust this kind of big organizations. They remember well, how much time and resources were spent by environmentalists during the reform of the 1970s to take care of the organisation's Image, while political leaders saw in them only the future electorate, which could lead to a balance of group interests.

As an electorate, the reformist environmentalists took a big step forward in the early seventies with regard to changes concerning, for example standards: designation of areas to be protected, determination of air and water quality standards, reduction of the danger of nuclear power plant sites, etc. They have negotiated with the leaders of trade unions or with oil companies in order to reach a compromise legal formulations. In America, a number of new organisations - such as the Environmental Protection Agency - were set up, whose main task was to monitor compliance with the environmental law.

However, the forces of action and decision-making of environmentalists and the forces of industrial oligarchical organizational structures were not, and are not, equal. In his extensive analysis of how the Environmental Protection Agency works, J. Quarles writes (1976, 320): "As long as our government is left alone, it will never care about public interests. In terms of environmental protection, there is a natural inequality. A private industry driven by the prospect of profit is exploiting and polluting our natural resources; it is using its natural advantage to exert political pressure, in order to overrule the environmental protec- 
tion laws. Manipulation related to industrial production explains, at least partially, why it is only when very serious environmental pollution occurs there is something done to stop it" (Devall 1997, 45).

Although, the environmental reform movements have not been involved in a bruising fight for their ideals, as it has been the case of other movements, and although, there is a continuous process of forming coalitions between individual reformist groups, which extends to the establishment of rights in the area of public interest - for example, the rights governing the maintenance of cleanliness of water and air, the rights relating to the use of land in Alaska - it is not possible for them to keep pace with the larger industrial concerns or to compete with them (e.g. with the oil industry). In some of those groups, as well as in certain governmental bodies dealing with environmental protection, there is a tendency to establish professional teams of experts (Devall 1970).

However, the representatives of deep ecology warn against this kind of professionalization of environmental protection, which, in their opinion, may be an obstacle to the fundamental transformation of society. R. Dasmann calls such experts 0-8-15 - environmental defenders, he writes: "The traditional environmental defender focuses his / her attention on certain types of animals and areas that he / she is interested in or associated with. [...] He / she probably respect the existing state and administrative management and seeks a favourable acceptance of a certain community. He / she is only reluctant to ask difficult questions because he / she fells dependent on wealthy people and government. He / she will certainly not question the whole system - the political, social and economic base of the country. As a work colleague or a colleague from a club of those who devastate nature the most, he / she comes well out of it; after all, he / she does not demand too much and, of course, is able to see the economic necessity and requirements of the real world (Devall 1997, 46-47).

Due to the lack of trust in hierarchical-bureaucratic or charismatic-fascist or- ganizations and models (e.g. People's Temple), the representatives of deep ecology connect with the loosely organized social groups. Those organisations are able to expand to such an extent, that they are able to communicate with each other, and adopt various forms. For example, Tutorenkolleg, referring to the spirit of medieval universities, offers modern courses of teaching (experiential experience) of new philosophy of nature (Carey 1977, 56). Others promote their views and ideas at various types of conferences or in magazines such as: Inquiry, Environmental Ethics or Eco-philosophy Newsletter. Among the first collection of books growing out of the trend of deep ecology one should include The Arrogance of Humanism (1979) by David Ehrenfeld and Gaia (1979) by John Lovelock.

Some social science theorists are trying to construct a new paradigm that should be followed by a social-scientific environmental theorist, but the still vivid positivist orientation of social science in America does not facilitate an understanding of the need to awaken ecological awareness among sociologists and philosophers of society. ${ }^{6}$ There are also those, who consider the reformist environmental movement to be "just one of the next movements", that are active in the politics of group interests of liberal states, as Th. Lowi calls modern American politics (Lowi 1969). However, deep ecology does not want to, by no means, be only one more group of interests that represents another ideology.

Generally, it can be said, that the task of deep ecology is to seek liberation and reconstruction in current science. Deep ecology has something of utopia, because it does not seek to conquer, control, or govern nature existing outside of a man, it does not seeks ways of a self-fulfilment. ${ }^{7}$ In his theory of post-industrial society, a sociologist

\footnotetext{
${ }^{6}$ On the criticism of positivist science see: (Nielsen 1979, 27; Naess. 1997, 64). On creating the environmental paradigm in sociology see: (Dunlap 1979, 57-85).

${ }^{7}$ It is about a self-fulfilment, according to Spinoza's point of view, as opposed to a self-sufficiency as a social objective. (Wienpahl 1979; Naess. 1973a, 53-57).
} 
D. Bell, describes this utopia as a certain vision of those prophets and intellectuals, who are at the forefront on their way to a new era: "This is how new utopias develop, out of necessity, in a post-industrial society, determined both by technology and a spirit. [...] Utopia of humanity is the constant search for harmonious and perfect mutual relations. In their wisdom, the Ancients, considered this aspiration to be unrealistic, but, a surely useful ideal [...] it could be an ideal measure of evaluation of people and reality.[...] Nowadays, attempts are being made to make this ideal a reality. This way, the ideal was devalued and the idea of utopia became unclear. Perhaps, it would not be a nonsense to go back to the classic concepts"(Devall 1997, 49).

To complete his study, B. Devall strongly emphasizes, that deep ecology triggers ecological awareness. The mentioned and quoted authors make radical criticisms of contemporary society and the fundamental values accepted by it. At least some of them propose deep, alternative changes of utopian nature. The development and deepening of ecological consciousness is a progressive process, therefore, all kinds of actions should be accompanied by this consciousness, which is the primary goal of the movement, opposed to ecological forms of protest. From a contemporary perspective, it must be said, that it is not often easy to articulate this environmental consciousness clearly and explicitly. Besides, it is not only about the theoretic and intellectual description of it, but above all, about its pragmatic dimension marked in the conviction: awareness is knowledge. According to the theorists of deep ecology, an ecological protest is a natural consequence of developing ecological awareness.

\section{Bibliography}

Adams, Ansel. 1961. "The Artist and the Ideals of Wilderness." In Wilderness, America's Living Heritage, edited by David Brower, 49-59. San Francisco: Sierra Club.

Barkan, Steven E. 1979. "Strategic, Tactical and Organizational Dilemmas of the Protest Movement Against Nuclear Power." Social Problems 27: 19-37.
Berg, Peter. 1978. Reinhabiting a Separate Country. San Francisco: Planet Drum Foundation.

Birnbacher, Dieter. 1997. „Vorbemerkung des Herausgebers." In Oekophilosophie, Hrsg. Dieter Birnbacher, 7-15. Stuttgart: Reclam.

Bond, Richard. 1977. "Salvationists, Utilitarians and Environmental Justice." Alternatives 6(3): 31-44.

Cahn, Robert. 1978. Footprints on the Planet. New York: Universe Books.

Capra, Fritjof. 1975. The Tao of Physics. Berkeley: Shambhala Publications.

Carey, Graham, and Peter Abbs. 1977. "Proposal for a New Ecological College." Ecologist 7: 56-60.

Castaneda, Carlos. 1971. A Separate Reality. New York: Cliffs Notes.

Castaneda, Carlos. 1974a. The Teachings of Don Juan. New York: Cliffs Notes.

Castaneda, Carlos. 1974b. Tales of Power. New York: Cliffs Notes.

Coffin, Arthur B. 1971. Robinson Jeffers: Poet of Inhumanism. Madison: University of Wisconsin Press.

Cole, Hugh S. D. 1973. Models of Doom: A Critique of the Limits to Growth. New York: Universe Books.

Collier, John. 1969. "The Fullness of Life Through Leisure." In The Subversive Science. Essays Toward an Ecology of Man, edited by Paul Shephard, and Daniel McKinley, 416436. Boston: Bostons Houghton Mifflin.

Commoner, Barry. 1971. The Closing Circle. New York: Bantam Books.

Daly, Herman. 1973. Toward a Steady State Economy. San Francisco: W. H. Freeman.

Dasmann, Raymond. 1973. Ecological Principles for Economic Development. New York: John Wiley \& Sons Inc.

Dasmann, Raymond. 1978. A Different Kind of Country. New York: The MacMillan Company. Devall, Bill. 1997. „Die tiefenoekologische Bewegung." In Oekophilosophie, Hrsg. Birnbacher, 17-59. Stuttgart: Reclam.

Devall, William. 1970. The Governing of a Voluntary Organization: Oligarchy and Democracy in the Sierra Club. Eugene: University of Oregon Press.

Dunlap Riley E., and William R. Catton Jr. 1979. "Environmental Sociology: a Framework for 
Analysis." In Progress in Resource Management and Environmental Planning, edited by Timothy O'Riordan, and R. Kerry Turner, 57-85. Chichester: John Wiley \& Sons.

Ehrlich, Paul R. 1968. The Population Bomb. New York: Ballantine Books.

Ehrlich, Paul R., Anne H. Ehrlich, and John P. Holdren. 1977. Ecoscience. San Francisco: W. H. Freeman.

Ellul, Jacques. 1964. The Technological Society. New York: Vintage Books.

Evernden, Neil. 1978. "Beyond Ecology" North American Review 263(4): 16-20.

Ferkiss, Victor C. 1974. The Future of Technological Civilization. New York.

Goodman, Paul. 1973. "Can Technology Be Humane?" In Western Man and Environmental Ethics, edited by Ian Barbour, 220231. Reading: Addison-Wesley.

Graves, Morris. 1974. The Drawings of Morris Graves. New York: New York Graphic Society.

Greenpeace. 1979. "Editorial." Greenpeace Chronicles 3.

Griffin, David. 1972. "Whitehead's Contribution to the Theology of Nature." The Bucknell Review 20: 95.

Hampshire, Stuart. 1956. Spinoza. Harmondsworth: Faber.

Hampshire, Stuart. 1977. Two theories of Morality. Oxford: British Academy.

Hardin, Garrett, and John Baden. 1977. Managing the Commons. San Francisco: Freeman.

Hays, Samuel P. 1959. Conservation and the Gospel of Efficiency. Cambridge (Mass.): Harvard University Press.

Heidegger, Martin. 1954. „Die Frage nach der Technik." In Vortraege und Aufsaetze, Hrsg. Martin Heidegger, 13-44. Pfullingen: Neske.

Hotchkiss, Bill. 1975. Jeffers: The Siviastic Vision. Auham: Blue Oak Press.

Huizinga, Johan. 1956. Homo Ludens, Vom Ursprung der Kultur im Spiel. Reinbek: Rowohlt Taschenbuch Verlag.

Huth, Hans. 1961. "Wilderness of Art." In Wilderness, America's Living Heritage, edited by David Brower, 55-69. San Francisco: Sierra Club.

Iltis, Hugh H. 1972. "Wilderness, can Man do without it?" In Recycle this Book: Ecology, Society and Man, edited by J. David Allan, and Arthur J. Hanson, 160-172. San Francisco: Wadsworth Pub.
LaChapelle, Dolores. 1978. Earth Wisdom. Los Angeles: Guild of Tutors Press.

Lasch, Christopher. 1979. The Culture of Narcissism: American Life in an Age of Diminishing Expectations. New York: W. W. Norton.

Leiss, William. 1976. The Limits to Satisfaction. An Essay on the Problem of Needs and Commodities. Toronto-Buffalo: University of Toronto Press.

Lovins, Amory B., and John H. Price. 1975. Non-nuclear Futures: The Case for an Ethical Energy Strategy. Cambridge (Mass): Ballinger Publishing Company.

Lowi, Theodore. 1969. The End of Liberalism. New York: W. W. Norton.

Marcuse, Herbert. 1964. One-dimensional Man. Boston: Beacon Press.

Masterman, Margaret. 1970. "The Nature of a Paradigm." In Criticism and the Growth of Knowledge, edited by Imre Lakatos, and Alan Musgrave, 63-64. Cambridge: Cambridge University Press.

McHarg, Ian L. 1971. Design with Nature. New York: Garden City.

Meadows, Denis L. 1977. Alternatives to Growth. Cambridge (Mass.): Ballinger.

Meadows, Donatella H., and Denis L. Meadows. 1974. The Limits to Growth. New York: Potomac Associates.

Mesarovic, Mihajlo D., and Eduard Pestel. 1974. Mankind at the Turning Point: Second Report of the Club of Rome. London: Dutton. Murdoch, William, and Joseph Connell. 1973. "All About Ecology." In Western Man and Environmental Ethics, edited by Ian Barbour, 156-170. Reading: Addison-Wesley.

Myers, Norman. 1979. The sinking Ark: A new look at the Problems of Disappearing Species. New York: Pergamon.

Naess, Arne. 1973a. "The Place of Joy in a World of Fact." North American Review 258(2): 53-57.

Naess, Arne. 1973b. "The Shallow and the Deep. Long-range Ecology Movement." Inquiry 16(1-4): 95-100.

Naess, Arne. 1977. "Spinoza and Ecology." Philosophia 7(1): 45-54.

Naess, Arne. 1997. "Notes on the Methodology of Normatives Systems." Methodology E Science 10: 64-79.

Nash, Hugh. 1977. Progress as if Survival Mattered. San Francisco: Friends of the Earth. 
Nash, Roderick F. 1973. Wilderness and the American Mind. New Haven: Yale Univ. Press.

Nash, Roderick F. 1977. "Do Rocks Have Rights?" Center Magazine 10: 2-12.

National Resources Defense Council. 1977. Land Use Controls in the United States: A Handbook of Legal Rights of Citizens. Washington: Dial Press.

Needham, Joseph. 1954. Science and Civilization in China. Cambridge: Cambridge University Press.

Needham, Joseph. 1976. "History and Human Values: A Chinese Perspective for World Science and Technology." Centennial Review 20: 1-35.

Needleman, Jacob. 1975. A Sense of the Cosmos. New York: Garden City.

Nielsen, Kai. 1979. "Reflections on Habermas." National Forum 69: 27-31.

Nisbet, Robert. 1974. The Social Philosophers: Community and Conflict in Western Thought. London: Heinemann Educ.

Odum, Eugene. 1973. Fundamentals of Ecology. Philadelphia: W. B. Saunders Company.

Ophuls, William. 1977. Ecology and the Politics of Scarcity. San Francisco: W. H. Freeman.

Ornstein, Robert. 1976. The Mind Field. New York: Grossman Publishers.

Passmore, John. 1974. Man's Responsibility for Nature. London: Duckworth.

Pinchot, Gifford. 1947. Breaking New Ground. New York: Harcourt.

Pirages, Dennis C., and Paul R. Ehrlich. 1974. Ark II: Social Response to Environmental Imperatives. San Francisco: W. H. Freeman.

Pirages, Dennis. 1977. The Sustainable Society. New York: Praeger.

Quarles, John. 1976. Cleaning up America. Boston: Houghton Mifflin.

Regan, Tom, and Peter Singer. 1976. Animal Rights and Human Obligation. Englewood-Cliffs: Prentice-Hall.

Report. 1972. Population and the American Future: Report of the Commission on Population Growth and the American Future. 1972. Washington: U.S. Government.

Ridgeway, James. 1970. The Politics of Ecology. New York: Dutton.

Roddewig, Richard. 1978. Green Bans. The Birth of Australian Environmental Politics. Sydney: Hale \& Iremonger.
Rodman, John. 1977a. "The Liberation of Nature?" Inquiry 20: 83-131.

Rodman, John. 1977b. Four Forms of Ecological Consciousness: Beyond Economics, Resource Conservation. Claremont: Pitzer College.

Rodman, John. 1978. "Theory and Practice in the Environmental Movement: Notes Towards an Ecology of Experience." In The Search for Absolute Values in a Changing World: Proceedings of the Sixth International Conference on the Unity of the Sciences, November 25-27, 1977, San Francisco, 48-59. New York: International Cultural Foundation Press.

Roszak, Theodore. 1969. The Making of a Counter-culture. New York: Garden City.

Roszak, Theodore. 1972. Where the Wasteland Ends: Politics and Transcendence in Postindustrial Society. New York: Garden City.

Roszak, Theodore. 1975. Unfinished Animal: The Aquarian Frontier and the Evolution of Consciousness. New York: Garden City.

Roszak, Theodore. 1978. Person / Planet. New York: Garden City.

Sax, Joseph L. 1971. Defending the Environment: A Strategy for Citizen Action. New York: Alfred A. Knopf.

Sax, Joseph L. 1976. "America's National Parks: Their Principles, Purposes and Their Prospects." Natural History 85: 57-87.

Schumacher, Ernst F. 1973. Small is Beautiful. Economics as if People Mattered. New York: Blond \& Briggs.

Sessions, George. 1977. "Spinoza and Jeffers on Man in Nature." Inquiry 20(1-4): 481-528.

Sheehan, Thomas. 1981. Heidegger: The Man and the Thinker. Chicago: Precedent.

Shepard, Paul. 1969. "Introduction: Man and Ecology." In The Subversive Science. Essays Toward an Ecology of Man, edited by Paul Shephard, and Daniel McKinley. Boston: Bostons Houghton Mifflin.

Shepard, Paul. 1973. The Tender Carnivore and the Sacred Game. New York: Scribner.

Shepard, Paul. 1977. "A Sense of Place." North American Review 262: 22.

Sibley, Mulford Q. 1977. Nature and Civilization: Some Implications for Politics. Itasca: F. E. Peacock Publishers.

Singer, Peter. 1975. Animal Liberation. New York: Harper Collins Publishers. 
Smith, Harper. 1976. Forgotten Truth. The Primordial Tradition. New York: Harper \& Row.

Smith, Houston. 1972. "Tao Now: An Ecological Testament." In Earth Might be Fair, edited by Ian Barbour, 62-81. Englewood-Cliffs: Prentice-Hall.

Snyder, Gary. 1970. "Four Changes." In The Environmental Handbook, edited by Garret de Bell, 320-332. New York: Ballantine Books.

Snyder, Gary. 1997. The Old Ways. San Francisco: City Lights Publishers.

Steiner, George. 1978. Martin Heidegger. Glasgow: Fontana Paperbacks.

Steuding, Bob. 1976. Gary Snyder. Boston: Twayne Publishers.

Suzuki, Daisetz T. 1961. Essays in Zen Buddhism. London: Grove Press.

Toulmin, Stephen. 1961. Foresight and Understanding. London: Hutchinson.

Train, Russell E. 1978. "The Environment Today." Science 201: 320-324.

Vycinias, Vincent. 1961. Earth and Gods: An Introduction to the Philosophy of Martin Heidegger. Den Haag: Martinus Nijhoff.
Watts, Alan. 1955. The Spirit of Zen: A Way of Life, Work and Art in the Far East. London: John Murray.

Watts, Alan. 1970. Nature, Man and Women. New York: Vintage Books.

Watts, Alan. 1975. Psychotherapy East and West. New York: Vintage Books.

Watts, Alan. 1977. The Essence of Alan Watts. Milbrae (CA): Celestial Arts.

Weisberg, Barry. 1971. Beyond Repair: The Ecology of Capitalism. Boston: Beacon Press.

White, Lynn. 1967. "The Historical Roots of Our Ecologic Crisis.” Science 155: 1203-1207.

Whitehead, Alfred N. 1925. Science and the Modern World. Cambridge: Cambridge University Press.

Wienpahl, Paul. 1979. The Radical Spinoza. New York: New York University Press.

Worster, Donald. 1977. Nature's Economy. San Francisco: Sierra Club Books.

Zimmerman, Michael E. 1977. "Beyond Humanism: Heidegger's Understanding of Technology." Listening 12: 74-83. 